\title{
Factor $\mathrm{H}$ and Neisserial pathogenesis
}

\author{
Jo Anne Welsch ${ }^{1}$ and Sanjay Ram ${ }^{2,3}$ \\ ${ }^{1}$ Children's Hospital of Oakland Research Institute, Oakland, CA \\ 2 Division of Infectious Diseases and Immunology, University of Massachusetts Medical Center, \\ Worcester, MA
}

\begin{abstract}
Both Neisseria gonorrhoeae and N. meningitidis bind to factor $\mathrm{H}$ which enhances their ability to evade complement dependent killing. While porin is the ligand for human $\mathrm{fH}$ on gonococci, meningococci use a lipoprotein called factor $\mathrm{H}$ binding protein (fHbp) to bind to factor $\mathrm{H}$ and enhance their ability to evade complement dependent killing. This protein is currently being intensively investigated as a meningococcal vaccine candidate antigen. Consistent with the observation that meningococci cause natural infection only in humans, the organism resists human complement, and are more readily killed by complement from lower animals. This human species-specific complement evasion has important implications for evaluation of vaccine-elicited antibodies using non-human complement sources and development of animal models of disease.
\end{abstract}

\section{Complement inhibition by factor $\mathrm{H}$}

Complement forms an important arm of innate immune defenses against invading pathogens. Complement activation leads to deposition of $\mathrm{C} 3$ fragments (C3b and $\mathrm{iC} 3 \mathrm{~b}$ ), which can enhance opsonophagocytosis of microbes. Subsequent activation of the terminal complement pathway results in direct complement-dependent killing of gram-negative bacteria. Microbes have developed several sophisticated mechanisms to limit complement activation on their surface to enable them to survive in their hosts.

One mechanism is binding of factor $\mathrm{H}$, which is the main fluid-phase inhibitor of the alternative complement pathway. Factor $\mathrm{H}$ acts as a cofactor for the factor I-mediated cleavage of $\mathrm{C} 3 \mathrm{~b}$ to the hemolytically inactive iC $3 \mathrm{~b}$ molecule [1-3]. Furthermore, factor $\mathrm{H}$ can cause irreversible dissociation of $\mathrm{C} 3 \mathrm{~b}, \mathrm{Bb}$ (alternative pathway $\mathrm{C} 3$ convertase) which is termed decayacceleration [4,5]. Factor $\mathrm{H}$ is composed entirely of 20 short consensus repeat (SCR) domains and each domain is composed of about 60 amino acids [6]. The first four $N$-terminal SCRs are sufficient for these cofactor and decay accelerating activities [7]. Binding of factor $\mathrm{H}$ to host cell surfaces [8-10] and microbes [11,12] occurs through one or more of the $15 \mathrm{C}$-terminal SCRs. Thus, binding factor $\mathrm{H}$ through domains distinct from its functional domains (SCRs 14) allows microbes the use of factor $\mathrm{H}$ to limit complement activation on their surface.

\footnotetext{
3Corresponding author: Division of Infectious Diseases and Immunology, Lazare Research Building, Room 322, 364 Plantation Street, Worcester, MA 01605, Phone: (508) 8566269 , Fax: (508) 856 5463, e-mail: sanjay.ram@umassmed.edu.

Publisher's Disclaimer: This is a PDF file of an unedited manuscript that has been accepted for publication. As a service to our customers we are providing this early version of the manuscript. The manuscript will undergo copyediting, typesetting, and review of the resulting proof before it is published in its final citable form. Please note that during the production process errors may be discovered which could affect the content, and all legal disclaimers that apply to the journal pertain.
} 


\section{Complement deficiencies and meningococcal infection}

The critical role of the terminal complement pathway in innate immune defenses against Neisserial disease is well illustrated by epidemiological observations that persons deficient in terminal complement proteins ( $\mathrm{C} 5, \mathrm{C} 6, \mathrm{C} 7, \mathrm{C} 8$ or $\mathrm{C} 9)$ suffer a very high incidence of invasive meningococcal disease compared to normal individuals [13-15]. For example, a study reported that the risk of meningococcal disease among C7- and C9-deficient Japanese was approximately 10,000- and 1,400-fold greater, respectively, than that in the complementsufficient Japanese population [16]. Interestingly, invasive meningococcal disease is the only infection that these individuals are more susceptible to. Alternative pathway deficiencies also are associated with a high incidence of meningococcal disease, as seen in families with properdin (X-linked recessive) [14,17-20] and factor D (autosomal recessive) [21] deficiencies.

Mortality in meningococcemia directly correlates with circulating endotoxin levels and the extent of complement activation [22]. Previous studies have shown that insertion of C5b-9 into the membrane of $E$. coli results in the release of lipid A from the bacterial membrane [23,24]. Consistent with this observation, an increase in circulating endotoxin levels were observed when a C6-deficient individual with meningococcemia was given fresh frozen plasma to correct coagulopathy, which also resulted in a temporary restoration of C6 levels [25]. Thus, at least one explanation for the lower mortality of persons with terminal complement levels may be lower lipid A release from meningococci with resulting lower circulating endotoxin levels. Persons with complement deficiency are more predisposed to invasive infections caused by less virulent serogroups such as W-135, Y, 29E and X, or by nongroupable isolates, which may also account for their lower mortality [14,15,26-28].

In contrast, properdin deficiency is associated with higher mortality [14]. Properdin stabilizes the alternative pathway C3/C5 convertases [29] and plays an important role in amplification of $\mathrm{C} 3$ deposition on the bacterial surface. This observation underscores the importance of the alternative pathway in defenses against meningococcal infections. Therefore, evasion of this pathway is important for the ability of the meningococcus to establish a niche in humans, its only known natural host.

\section{Factor $\mathrm{H}$ and meningococcal disease}

Approximately 15 families with factor $\mathrm{H}$ deficiency have been reported [30]. Complete deficiency of factor $\mathrm{H}$ results in uncontrolled alternative pathway activation and consumption of complement components C3 and factor B and reduced or absent AP50 and CH50 levels. Uninhibited complement activation results in membranoproliferative glomerulonephritis (also called measangiocapillary glomerulonephritis), a condition characterized by thickening of the glomerular capillary wall together with hypercellularity in mesangial areas. Because of the lack of functional $\mathrm{C}$, such persons are also predisposed to invasive meningococcal disease.

Conversely, higher levels of factor $\mathrm{H}$ may be disadvantageous for the host because an excess of factor $\mathrm{H}$ relative to complement activatory molecules may impede optimal complement activation. A fine balance between the activatory and inhibitory arms of the complement system ensures that complement is activated appropriately on invading pathogens. While too much activation will result in host tissue damage, excessive regulation could facilitate microbial survival in vivo. Accordingly, a polymorphism in the NF-kB responsive element in the promoter region of factor $\mathrm{H}(\mathrm{C}-496 \mathrm{~T})$ that results in higher factor $\mathrm{H}$ levels increases susceptibility to disease by a factor of $\sim 2$ [31]. The association of the $\mathrm{C} / \mathrm{C}$ homozygous phenotype with serogroup $\mathrm{C}$ disease was even stronger (odds ration 2.9). Adding pure factor $\mathrm{H}$ to whole blood increased survival of serogroups $\mathrm{A}$ and $\mathrm{C}$, but not serogroup $\mathrm{B}$, meningococci [31]. 


\section{Lipooligosaccharide sialylation: the contrasts between gonococci and meningococci}

Previous work has shown that Neisseria gonorrhoeae bind to factor $\mathrm{H}$ to down-regulate complement. Certain gonococcal isolates bind to factor $\mathrm{H}$ and become resistant to serum only when their lipooligosaccharide (LOS) is sialylated [32]. This is termed 'unstable serum resistance' because reversion to the serum sensitive phenotype occurs when the bacteria are passaged on media without added cytidinemonophospho- $N$-acetylneuraminic acid (CMPNANA), the donor molecular for sialic acid. Two LOS structures can serve as acceptors for sialic acid (i) the lacto-N-neotetraose (LNT) LOS $(\mathrm{Gal} \beta 1 \rightarrow 4 \mathrm{GlcNAc} \beta 1 \rightarrow 3 \mathrm{Gal} \beta 1 \rightarrow 4 \mathrm{Glc} \beta 1 \rightarrow 4 \mathrm{Hep} 1)$ and the $\mathrm{P}^{\mathrm{K}}$-like $\mathrm{LOS}(\mathrm{Gal} \alpha 1 \rightarrow 4 \mathrm{Gal}$ $\beta 1 \rightarrow 4 \mathrm{Glc} \beta 1 \rightarrow 4 \mathrm{Hep} 1)$. Sialylation of only LNT LOS, but not the $\mathrm{P}^{\mathrm{K}}$-like LOS results in enhanced factor $\mathrm{H}$ binding [33]. Certain strains of $N$. gonorrhoeae that express the porin (Por) 1A molecule (now designated PorB.1A) can bind to factor $\mathrm{H}$ and are serum resistant even when their LOS molecule is not sialylated [34]. This is termed stable serum resistance and stably serum resistant strains often cause extragenital manifestations such as tenosynovitis and septic arthritis (disseminated gonococcal infection) [35,36].

While sialylation of gonococcal LNT LOS results in enhanced factor H binding, sialylation of LNT LOS in meningococci does not result in increased factor $\mathrm{H}$ binding. The reason for this difference among the two species is the requirement for the concomitant expression of gonococcal Por; allelic replacement of meningococcal PorB with gonococcal PorB results in increased factor $\mathrm{H}$ binding when meningococcal LOS is sialylated [37].

\section{Identification of the ligand for factor $\mathrm{H}$ on meningococci}

Akin to gonococci, meningococci also bind to factor $\mathrm{H}$ and it was initially speculated that meningococcal PorB 3 was the ligand for factor $\mathrm{H}$ based on its homology to gonococcal PorB. 1A [38]. While purified PorB3 was shown to bind to factor $\mathrm{H}$ in an ELISA assay [39], two lines of evidence suggested that PorB3 was not the acceptor for factor $\mathrm{H}$ on intact bacteria. First, deletion of PorB3 did not result in decreased factor $\mathrm{H}$ binding to bacteria [40,41], and second, allelic replacement of porB2 of a factor $\mathrm{H}$ nonbinding strain with porB3 from a factor $\mathrm{H}$ binding strain did not restore factor $\mathrm{H}$ binding [40].

Immunoblotting of meningococcal cell lysates and membrane preparations identified a 29 $\mathrm{kD}$ target for factor $\mathrm{H}[40,41]$ and MALDI-TOF analysis identified the target as genomederived Neisserial antigen (GNA) 1870 (also called LP2086) [40]. GNA1870 was confirmed to be a target for factor $\mathrm{H}$ on whole bacteria by (i) deleting gnal870 and abrogating factor $\mathrm{H}$ binding and (ii) by blocking factor $\mathrm{H}$ binding with specific anti-GNA1870 mAbs [40].

Two classification schemes currently exist for GNA1870/LP2086 based on DNA sequence analysis and immunochemical reactivity. The system proposed by Masignani et al divided GNA1870 into variant 1, 2 and 3 proteins [42], while Fletcher et al classified LP2086 into A and B subfamilies [43]. Both groups are currently in Phase 1 and 2 clinical trials testing vaccines with formulations containing fHbp as a principal antigen. Regardless of the nomenclature used, factor $\mathrm{H}$ binds to all variants or families of GNA1870 or LP2086, respectively [40]. However, the expression level of GNA1870/LP2086 varies across meningococcal strains [42,43] and the amount of factor $\mathrm{H}$ binding to bacteria parallels fHbp expression levels; strains that express very low levels of the lipoprotein show no detectable factor $\mathrm{H}$ binding by flow cytometry [40]. We have found that select monoclonal antibodies specific to meningococcal fHbp inhibit this binding of factor $\mathrm{H}$ to $\mathrm{fHbp}$. 


\section{N. gonorrhoeae also possess gna1870}

The gonococcal homologue of fHbp, NGO033, is not predicted to contain a signal sequence to direct membrane localization or lipid modification. In naturally occurring isolates, the presence of a "G residue" after position 36 (relative to the MC58 sequence) shifts the reading frame and results in loss of the signal peptidase II motif. Homology with the meningococcal fHbp is restored by an 8 bp insertion (CGGAGGCG) after position 73. When examined on western blot the gonococcal fHbp is approximately $6 \mathrm{kD}$ larger than the meningococcal protein, consistent with a lack of signal peptide cleavage. Not surprisingly, deleting the fHbp homolog in gonococci did not result in decreased factor $\mathrm{H}$ binding or an alteration in serum resistance (our unpublished observations), consistent with the lack of a signal sequence which would predict that this protein is located in the cytoplasm. The function of the gonococcal fHbp homolog remains unclear.

\section{Functional significance of factor $\mathbf{H}$ binding to meningococci}

GNA1870/LP2086 was renamed factor $\mathrm{H}$ binding protein (fHbp) after a series of studies elaborated the importance of this protein to Neisseria meningitidis' survival in human serum. In a bactericidal assay, Schneider et al showed increased killing of meningococci in human serum depleted of factor $\mathrm{H}$ compared to the same serum reconstituted with physiological amounts of factor H [41]. Similarly, insertional inactivation of gnal870 deleting protein expression, prevented binding of factor $\mathrm{H}$ directly to the bacterial surface, and resulted in increased sensitivity of bacteria to complement-dependent killing in a serum bactericidal assay [40]. The dependence of a strain on fHbp for its survival in blood appears to vary with the level of fHbp expressed. When fHbp is deleted in high fHbp expresser strains, the strain is unable to survive in nonimmune human blood whereas the corresponding wildtype strain thrives [44]. In contrast, when fHbp is deleted from strains naturally expressing low amounts of the protein, the bacteria are able to grow in nonimmune human blood similarly to the corresponding wildtype strains (Fig. 1). Thus, although the functional significance of fHbp for the survival of the bacteria in the human host is clear, these data imply that there are additional alternate survival mechanisms employed by the low expressing strains. It is important to note that while binding of factor $\mathrm{H}$ to PorB.1A-bearing or sialylated PorB.1B gonococci results in high levels of serum resistance [32,34], factor $\mathrm{H}$ binding to meningococci that lack a capsule does not result in the same degree of serum resistance. Thus capsular polysaccharide expression remains necessary for high-level meningococcal serum resistance and for virulence [45-49].

\section{fHbp as a vaccine candidate}

Prior to the discovery that the protein bound human factor $\mathrm{H}$, fHbp was simultaneously identified by two different groups $[42,43]$ as a highly immunogenic, universally expressed vaccine candidate against group B disease. As a vaccine fHbp is appealing because the expression of the protein by the bacteria enhances serum resistance. Thus, variants that do not express fHbp as a result of selection pressure by vaccine elicited antibodies will likely be relatively serum sensitive and at a survival disadvantage.

Expression levels of fHbp determine the bactericidal efficacy of anti-fHbp mAbs. Certain murine mAbs, and particularly those that belong to the IgG3 subclass such as JAR 3, were bactericidal against strains that express high levels of fHbp (such as strain H44/76) but not against low fHbp expressing strains (such as NZ98/254). A likely explanation for this observation is that epitope density on high fHbp expressing strains is adequate to permit $\mathrm{Clq}$ engagement by adjacent $\mathrm{Fc}$ domains with subsequent $\mathrm{C} 4$ activation and $\mathrm{C} 4 \mathrm{~b}$ deposition. In contrast, the distance between $\mathrm{Fc}$ domains on low expressers is too great to allow $\mathrm{C} 1 \mathrm{q}$ binding. Consistent with this hypothesis, JAR 3 bound only to a high fHbp-expressing strain, but not to a low fHbp expresser, could mediate $\mathrm{C} 4 \mathrm{~b}$ deposition. However combination of anti-fHbp 
mAbs (JAR 3 plus JAR 4) could overcome the obstacle of low epitope density and mediate $\mathrm{C} 4 \mathrm{~b}$ binding to the low fHbp expressing strain (Fig. 2) [50,51]. Additionally, mutants overexpressing fHbp are more susceptible to bactericidal activity of fHbp specific monoclonal antibodies [44]. Some of these mAbs inhibit binding of factor $\mathrm{H}$ to the surface of the bacteria, which could contribute to enhanced bactericidal activity of the mAbs due to increased serum sensitivity.

\section{Species specificity of factor $\mathrm{H}$ binding to Neisseriae and its implications}

We have shown previously that serum resistance of $N$. gonorrhoeae is species-specific. $N$. gonorrhoeae bind to human complement inhibitory proteins such as $\mathrm{C} 4 \mathrm{bp}$-binding protein (C4BP; classical pathway inhibitor) and factor $\mathrm{H}$ in a species-specific manner. PorB.1Bbearing strains that can bind to human C4BP can also bind to chimpanzee C4BP and resist chimpanzee serum [52]. However, all serum resistant strains of $N$. gonorrhoeae strains tested so far are susceptible to killing by complement from other primates such as baboons and rhesus, and lower animals such as rabbits, guinea pigs and rats. Adding purified human $\mathrm{C} 4 \mathrm{BP}$ or factor $\mathrm{H}$ to nonhuman sera restores the ability of $N$. gonorrhoeae to resist heterologous complement [52]. These results may in part explain the restriction of natural gonococcal infection to humans.

Akin to N. gonorrhoeae, $N$. meningitidis is a human specific pathogen. To investigate the underlying reason, we first compared binding of factor $\mathrm{H}$ present in human serum to $N$. meningitidis with factor $\mathrm{H}$ from other primates (chimpanzee, baboon and rhesus macaque). Compared to human factor $\mathrm{H}$, we found weak binding to chimpanzee factor $\mathrm{H}$ and barely detectable binding to rhesus macaque and baboon factor $\mathrm{H}$ [53]. Furthermore, several meningococcal strains that express high levels of fHbp and resist killing by human complement are readily killed by infant rat complement. Adding purified human factor $\mathrm{H}$ to infant rat serum restores the ability of meningococci to resist complement-dependent killing.

Species-specificity of factor $\mathrm{H}$ binding has two important implications. First, baby rabbit complement which is often used as a complement source to evaluate the efficacy of killing by antibodies elicited by vaccination of humans yields higher killing titers than human complement [54,55]. These higher titers may result from lack of down-regulatory effects of rabbit factor $\mathrm{H}$, which does not bind to the meningococcal surface. Consistent with this hypothesis, we have shown that adding purified human factor $\mathrm{H}$ to baby rabbit complement resulted in a 8- to 60-fold drop in serum bactericidal titers of polysaccharide vaccine recipients to levels that more closely resemble that seen with human complement. Second, any in vivo animal models of meningococcal bacteremia [56-59] are inherently flawed because of the inability of non-human factor $\mathrm{H}$ to bind to bacteria and inhibit complement activation on the bacterial surface. Absence of bound factor $\mathrm{H}$ will increase serum sensitivity of the bacteria, making the bacteria easier to kill than would be the case in a human system. We have observed that administering purified human factor $\mathrm{H}$ concomitantly with bacteria in the infant rat model increased the level of bacteremia. This observation provides the rationale to create transgenic animals that express human factor $\mathrm{H}$ in order to have a more biologically relevant in vivo model.

\section{CONCLUSIONS}

Factor $\mathrm{H}$ plays a key role for both $N$. gonorrhoeae and $N$. meningitidis to evade complement dependent killing. We have described the different ligands for factor $\mathrm{H}$ on the two species. Gonococci lack a capsule and rely on binding of complement inhibitors to survive in the human host. On the other hand, meningococci rely on capsular polysaccharide expression for highlevel serum resistance and virulence. The crucial role of fHbp is illustrated by the fact that all invasive isolates express this protein, albeit in varying amounts. High expressers of fHbp are dependent on binding factor $\mathrm{H}$ for survival in human blood. Although binding of factor $\mathrm{H}$ to 
strains that are naturally low expressers of fHbp also may increase the ability of the organism to evade human innate host defenses, the low-expressing strains likely also possess additional mechanisms of complement evasion. Studies of fHbp expression in carriage isolates will shed light on the importance of this molecule in causing invasive disease. The species-specific binding of factor $\mathrm{H}$ to both $N$. gonorrhoeae and $N$. meningitidis provides another reason for the human-specific nature of Neisserial infection. Creation of transgenic animals that express human complement inhibitors will improve existing animal models of gonorrhea and meningococcemia. Finally, detailed structural analysis of factor H-fHbp interactions may aid development vaccines and therapeutic molecules.

\section{Acknowledgments}

S.R is supported by National Institutes of Health grants AI054544 and AI32725, and J.W by R01 AI46464. We thank Dr. Dan Granoff for critically reading the manuscript.

\section{References}

1. Pangburn MK, Schreiber RD, Muller-Eberhard HJ. Human complement C3b inactivator: isolation, characterization, and demonstration of an absolute requirement for the serum protein beta $1 \mathrm{H}$ for cleavage of C3b and C4b in solution. J Exp Med 1977;146(1):257-70. [PubMed: 301546]

2. Sim RB, DiScipio RG. Purification and structural studies on the complement-system control protein beta 1H (Factor H). Biochem J 1982;205(2):285-93. [PubMed: 6215918]

3. Whaley K, Ruddy S. Modulation of the alternative complement pathways by beta $1 \mathrm{H}$ globulin. J Exp Med 1976;144(5):1147-63. [PubMed: 62817]

4. Fearon DT. Regulation by membrane sialic acid of $\beta 1 \mathrm{H}$-dependent decay-dissociation of amplification C3 convertase of the alternative complement pathway. Proc Natl Acad Sci USA 1978;75:1971-75. [PubMed: 273923]

5. Kazatchkine MD, Fearon DT, Austen KF. Human alternative complement pathway: membraneassociated sialic acid regulates the competition between $\mathrm{B}$ and beta1 $\mathrm{H}$ for cell-bound $\mathrm{C} 3 \mathrm{~b}$. J Immunol 1979;122(1):75-81. [PubMed: 762425]

6. Ripoche J, Day AJ, Harris TJ, Sim RB. The complete amino acid sequence of human complement factor H. Biochem J 1988;249(2):593-602. [PubMed: 2963625]

7. Gordon DL, Kaufman RM, Blackmore TK, Kwong J, Lublin DM. Identification of complement regulatory domains in human factor H. J Immunol 1995;155(1):348-56. [PubMed: 7541419]

8. Jokiranta TS, Cheng ZZ, Seeberger H, Jozsi M, Heinen S, Noris M, et al. Binding of complement factor $\mathrm{H}$ to endothelial cells is mediated by the carboxy-terminal glycosaminoglycan binding site. Am J Pathol 2005;167(4):1173-81. [PubMed: 16192651]

9. Ormsby RJ, Jokiranta TS, Duthy TG, Griggs KM, Sadlon TA, Giannakis E, et al. Localization of the third heparin-binding site in the human complement regulator factor H1. Mol Immunol 2006;43(10): 1624-32. [PubMed: 16263173]

10. Schmidt CQ, Herbert AP, Kavanagh D, Gandy C, Fenton CJ, Blaum BS, et al. A new map of glycosaminoglycan and C3b binding sites on factor H. J Immunol 2008;181(4):2610-9. [PubMed: 18684951]

11. Wurzner R. Evasion of pathogens by avoiding recognition or eradication by complement, in part via molecular mimicry. Mol Immunol 1999;36(4-5):249-60. [PubMed: 10403478]

12. Kraiczy P, Wurzner R. Complement escape of human pathogenic bacteria by acquisition of complement regulators. Mol Immunol 2006;43(1-2):31-44. [PubMed: 16011850]

13. Figueroa J, Andreoni J, Densen P. Complement deficiency states and meningococcal disease. Immunol Res 1993;12(3):295-311. [PubMed: 8288947]

14. Ross SC, Densen P. Complement deficiency states and infection: epidemiology, pathogenesis and consequences of neisserial and other infections in an immune deficiency. Medicine (Baltimore) 1984;63(5):243-73. [PubMed: 6433145] 
15. Fijen CA, Kuijper EJ, te Bulte MT, Daha MR, Dankert J. Assessment of complement deficiency in patients with meningococcal disease in The Netherlands. Clin Infect Dis 1999;28(1):98-105. [PubMed: 10028078]

16. Nagata M, Hara T, Aoki T, Mizuno Y, Akeda H, Inaba S, et al. Inherited deficiency of ninth component of complement: an increased risk of meningococcal meningitis. J Pediatr 1989;114(2):260-4. [PubMed: 2915285]

17. Densen P, Weiler JM, Griffiss JM, Hoffmann LG. Familial properdin deficiency and fatal meningococcemia. Correction of the bactericidal defect by vaccination. N Engl J Med 1987;316(15): 922-6. [PubMed: 3102964]

18. Sjoholm AG, Braconier JH, Soderstrom C. Properdin deficiency in a family with fulminant meningococcal infections. Clin Exp Immunol 1982;50(2):291-7. [PubMed: 7151327]

19. Braconier JH, Sjoholm AG, Soderstrom C. Fulminant meningococcal infections in a family with inherited deficiency of properdin. Scand J Infect Dis 1983;15(4):339-45. [PubMed: 6658381]

20. Soderstrom C, Sjoholm AG, Svensson R, Ostenson S. Another Swedish family with complete properdin deficiency: association with fulminant meningococcal disease in one male family member. Scand J Infect Dis 1989;21(3):259-65. [PubMed: 2502833]

21. Biesma DH, Hannema AJ, van Velzen-Blad H, Mulder L, van Zwieten R, Kluijt I, et al. A family with complement factor D deficiency. J Clin Invest 2001;108(2):233-40. [PubMed: 11457876]

22. Brandtzaeg P, Mollnes TE, Kierulf P. Complement activation and endotoxin levels in systemic meningococcal disease. J Infect Dis 1989;160(1):58-65. [PubMed: 2471750]

23. Tesh VL, Duncan RL Jr, Morrison DC. The interaction of Escherichia coli with normal human serum: the kinetics of serum-mediated lipopolysaccharide release and its dissociation from bacterial killing. J Immunol 1986;137(4):1329-35. [PubMed: 3525676]

24. O'Hara AM, Moran AP, Wurzner R, Orren A. Complement-mediated lipopolysaccharide release and outer membrane damage in Escherichia coli J5: requirement for C9. Immunology 2001;102(3):36572. [PubMed: 11298837]

25. Lehner PJ, Davies KA, Walport MJ, Cope AP, Wurzner R, Orren A, et al. Meningococcal septicaemia in a C6-deficient patient and effects of plasma transfusion on lipopolysaccharide release. Lancet 1992;340(8832):1379-81. [PubMed: 1360091]

26. Fijen CA, Kuijper EJ, Hannema AJ, Sjoholm AG, van Putten JP. Complement deficiencies in patients over ten years old with meningococcal disease due to uncommon serogroups. Lancet 1989;2(8663): 585-8. [PubMed: 2570284][see comments]

27. Fijen CA, Kuijper EJ, Tjia HG, Daha MR, Dankert J. Complement deficiency predisposes for meningitis due to nongroupable meningococci and Neisseria-related bacteria. Clin Infect Dis 1994;18 (5):780-4. [PubMed: 8075270]

28. Orren A, Caugant DA, Fijen CA, Dankert J, van Schalkwyk EJ, Poolman JT, et al. Characterization of strains of Neisseria meningitidis recovered from complement-sufficient and complement-deficient patients in the Western Cape Province, South Africa. J Clin Microbiol 1994;32(9):2185-91. [PubMed: 7814544]

29. Fearon DT, Austen KF. Properdin: binding to C3b and stabilization of the C3b-dependent C3 convertase. J Exp Med 1975;142(4):856-63. [PubMed: 1185108]

30. Pickering MC, Cook HT. Translational mini-review series on complement factor H: renal diseases associated with complement factor $\mathrm{H}$ : novel insights from humans and animals. Clin Exp Immunol 2008;151(2):210-30. [PubMed: 18190458]

31. Haralambous E, Dolly SO, Hibberd ML, Litt DJ, Udalova IA, O'Dwyer C, et al. Factor H, a regulator of complement activity, is a major determinant of meningococcal disease susceptibility in UK Caucasian patients. Scand J Infect Dis 2006;38(9):764-71. [PubMed: 16938729]

32. Ram S, Sharma AK, Simpson SD, Gulati S, McQuillen DP, Pangburn MK, et al. A novel sialic acid binding site on factor $\mathrm{H}$ mediates serum resistance of sialylated Neisseria gonorrhoeae. J Exp Med 1998;187(5):743-52. [PubMed: 9480984]

33. Gulati S, Cox A, Lewis LA, Michael FS, Li J, Boden R, et al. Enhanced factor H binding to sialylated gonococci is restricted to the sialylated lacto-N-neotetraose lipooligosaccharide species: implications for serum resistance and evidence for a bifunctional lipooligosaccharide sialyltransferase in gonococci. Infect Immun 2005;73(11):7390-7. [PubMed: 16239538] 
34. Ram S, McQuillen DP, Gulati S, Elkins C, Pangburn MK, Rice PA. Binding of complement factor $\mathrm{H}$ to loop 5 of porin protein 1A: a molecular mechanism of serum resistance of nonsialylated Neisseria gonorrhoeae. J Exp Med 1998;188(4):671-80. [PubMed: 9705949]

35. Schoolnik GK, Buchanan TM, Holmes KK. Gonococci causing disseminated gonococcal infection are resistant to the bactericidal action of normal human sera. J Clin Invest 1976;58(5):1163-73. [PubMed: 825532]

36. O'Brien JP, Goldenberg DL, Rice PA. Disseminated gonococcal infection: a prospective analysis of 49 patients and a review of pathophysiology and immune mechanisms. Medicine 1983;62:395-406. [PubMed: 6415361]

37. Madico G, Ngampasutadol J, Gulati S, Vogel U, Rice PA, Ram S. Factor H Binding and function in sialylated pathogenic Neisseriae is Influenced by gonococcal, but not meningococcal, Porin. J Immunol 2007;178(7):4489-97. [PubMed: 17372007]

38. Ram S, Mackinnon FG, Gulati S, McQuillen DP, Vogel U, Frosch M, et al. The contrasting mechanisms of serum resistance of Neisseria gonorrhoeae and Neisseria meningitidis. Mol Immunol 1999;4-5(2):915-28.

39. Estabrook MM, Jack DL, Klein NJ, Jarvis GA. Mannose-binding lectin binds to two major outer membrane proteins, opacity protein and porin, of Neisseria meningitidis. J Immunol 2004;172(6): 3784-92. [PubMed: 15004183]

40. Madico G, Welsch JA, Lewis LA, McNaughton A, Perlman DH, Costello CE, et al. The meningococcal vaccine candidate GNA1870 binds the complement regulatory protein factor $\mathrm{H}$ and enhances serum resistance. J Immunol 2006;177(1):501-10. [PubMed: 16785547]

41. Schneider MC, Exley RM, Chan H, Feavers I, Kang YH, Sim RB, et al. Functional significance of factor H binding to Neisseria meningitidis. J Immunol 2006;176(12):7566-75. [PubMed: 16751403]

42. Masignani V, Comanducci M, Giuliani MM, Bambini S, Adu-Bobie J, Arico B, et al. Vaccination against Neisseria meningitidis using three variants of the lipoprotein GNA1870. J Exp Med 2003;197 (6):789-99. [PubMed: 12642606]

43. Fletcher LD, Bernfield L, Barniak V, Farley JE, Howell A, Knauf M, et al. Vaccine potential of the Neisseria meningitidis 2086 lipoprotein. Infect Immun 2004;72(4):2088-100. [PubMed: 15039331]

44. Welsch JA, Ram S, Koeberling O, Granoff DM. Complement-dependent synergistic bactericidal activity of antibodies against factor H-binding protein, a sparsely distributed meningococcal vaccine antigen. J Infect Dis 2008;197(7):1053-61. [PubMed: 18419542]

45. Geoffroy MC, Floquet S, Metais A, Nassif X, Pelicic V. Large-scale analysis of the meningococcus genome by gene disruption: resistance to complement-mediated lysis. Genome Res 2003;13(3):3918. [PubMed: 12618369]

46. Mackinnon FG, Borrow R, Gorringe AR, Fox AJ, Jones DM, Robinson A. Demonstration of lipooligosaccharide immunotype and capsule as virulence factors for Neisseria meningitidis using an infant mouse intranasal infection model. Microb Pathog 1993;15(5):359-66. [PubMed: 7912406]

47. Vogel U, Frosch M. Mechanisms of neisserial serum resistance. Mol Microbiol 1999;32(6):1133-9. [PubMed: 10383755]

48. Vogel U, Hammerschmidt S, Frosch M. Sialic acids of both the capsule and the sialylated lipooligosaccharide of Neisseria meningitidis serogroup B are prerequisites for virulence of meningococci in the infant rat. Med Microbiol Immunol (Berl) 1996;185(2):81-7. [PubMed: 8884739]

49. Vogel U, Weinberger A, Frank R, Muller A, Kohl J, Atkinson JP, et al. Complement factor C3 deposition and serum resistance in isogenic capsule and lipooligosaccharide sialic acid mutants of serogroup B Neisseria meningitidis. Infect Immun 1997;65(10):4022-9. [PubMed: 9317002]

50. Beernink PT, Welsch JA, Bar-Lev M, Koeberling O, Comanducci M, Granoff DM. Fine antigenic specificity and cooperative bactericidal activity of monoclonal antibodies directed at the meningococcal vaccine candidate factor h-binding protein. Infect Immun 2008;76(9):4232-40. [PubMed: 18591239]

51. Welsch JA, Rossi R, Comanducci M, Granoff DM. Protective activity of monoclonal antibodies to genome-derived neisserial antigen 1870, a Neisseria meningitidis candidate vaccine. J Immunol 2004;172(9):5606-15. [PubMed: 15100304] 
52. Ngampasutadol J, Ram S, Blom AM, Jarva H, Jerse AE, Lien E, et al. Human C4b-binding protein selectively interacts with Neisseria gonorrhoeae and results in species-specific infection. Proc Natl Acad Sci U S A 2005;102(47):17142-7. [PubMed: 16275906]

53. Welsch, JA.; Ram, S.; Granoff, DM. In: van Alphen, L.; van der Ley, P.; van den Dobbelsteen, G., editors. Implications of human species-specific binding of complement factor $\mathrm{H}$ to Neisseria meningitidis for assaying functional activity of vaccine-induced serum antibodies using non-human complement; 16th International Pathogenic Neisseria Conference; 2008; Rotterdam. 2008. p. 152-53.

54. Santos GF, Deck RR, Donnelly J, Blackwelder W, Granoff DM. Importance of complement source in measuring meningococcal bactericidal titers. Clin Diagn Lab Immunol 2001;8(3):616-23. [PubMed: 11329468]

55. Zollinger WD, Mandrell RE. Importance of complement source in bactericidal activity of human antibody and murine monoclonal antibody to meningococcal group B polysaccharide. Infect Immun 1983;40(1):257-64. [PubMed: 6403466]

56. Hou VC, Koeberling O, Welsch JA, Granoff DM. Protective antibody responses elicited by a meningococcal outer membrane vesicle vaccine with overexpressed genome-derived neisserial antigen 1870. J Infect Dis 2005;192(4):580-90. [PubMed: 16028126]

57. Saukkonen K. Experimental meningococcal meningitis in the infant rat. Microb Pathog 1988;4(3): 203-11. [PubMed: 3193872]

58. Toropainen M, Kayhty H, Saarinen L, Rosenqvist E, Hoiby EA, Wedege E, et al. The infant rat model adapted to evaluate human sera for protective immunity to group B meningococci. Vaccine 1999;17 (20-21):2677-89. [PubMed: 10418919]

59. Toropainen M, Saarinen L, Wedege E, Bolstad K, Makela PH, Kayhty H. Passive protection in the infant rat protection assay by sera taken before and after vaccination of teenagers with serogroup $B$ meningococcal outer membrane vesicle vaccines. Vaccine 2005;23(40):4821-33. [PubMed: 15970361] 


\section{Donor 1}

MC58

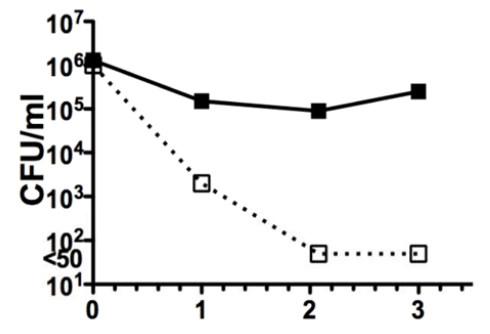

H44/76

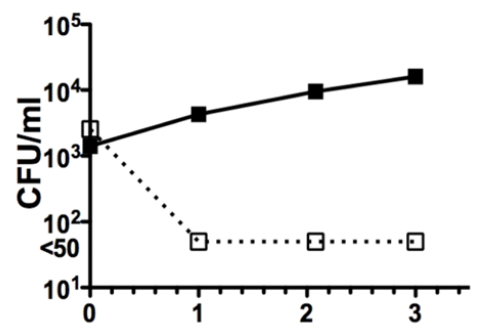

NZ98/

254

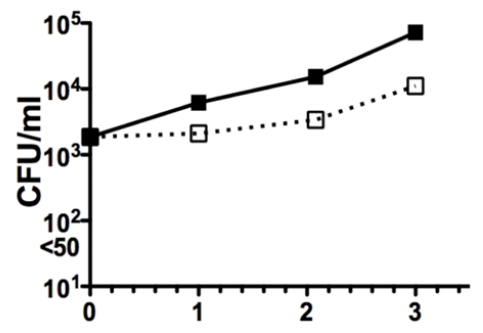

4243

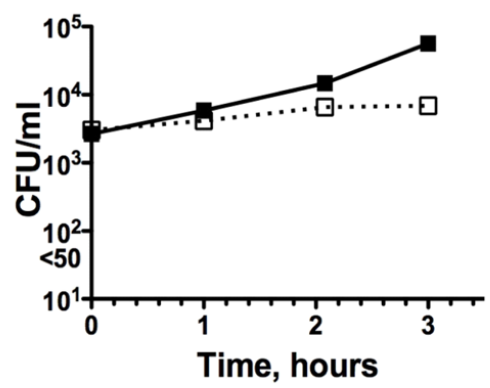

\section{Donor 2}
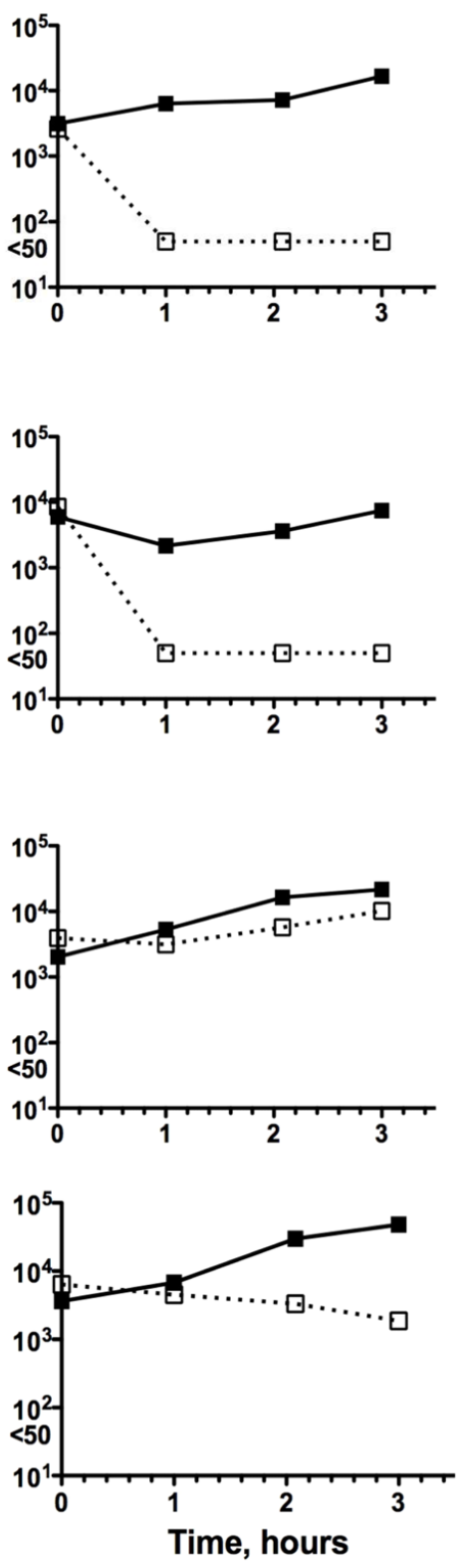

Figure 1.

Survival of wild-type meningococci and their fHbp deletion mutants in human blood. Meningococcal strains MC58 and H44/76 (high fHbp expressers) and NZ98/254 and 4243 (low fHbp expressers) and their fHbp deletion mutants were examined for their ability to survive in whole blood derived from two individual donors. Survival of the wild-type strains and their respective fHbp mutants are shown by the solid and broken lines, respectively. Loss of fHbp on only the high expressers, but not the low expressers, compromised bacterial survival. The data are from Ref. [44]. 


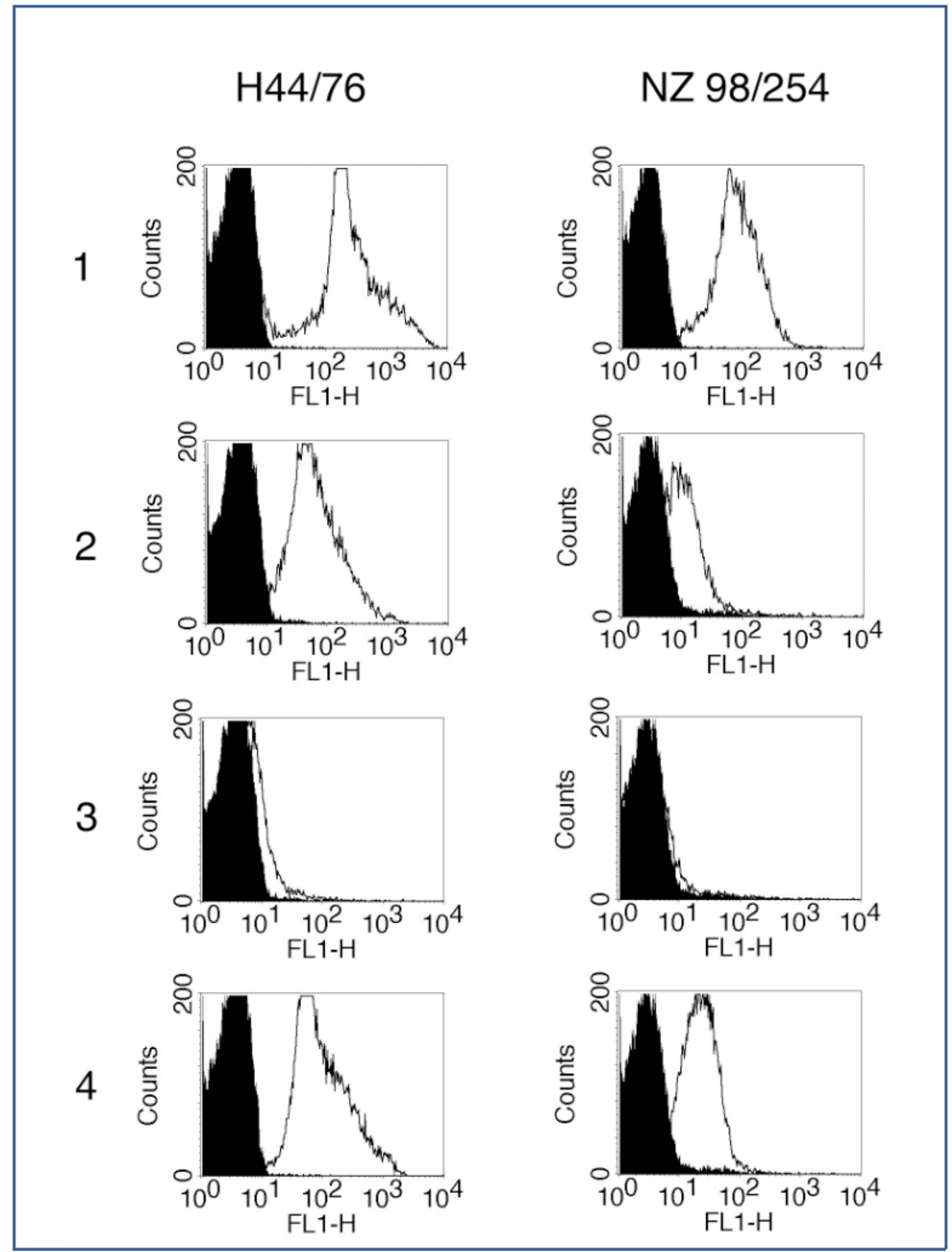

Figure 2.

Binding of human $\mathrm{C} 4 \mathrm{~b}$ to the surface of live encapsulated Neisseria meningitidis cells, as determined by indirect fluorescence flow cytometry. The left column shows results for the group B strain H44/76 (high fHbp expresser), and the right column shows results for the group B strain NZ98/254 (low fHbp expresser). Black areas in histograms indicate bacteria with 5\% nonimmune human serum, and white areas indicate bacteria with monoclonal antibodies and 5\% nonimmune human serum. Row 1: left, anti-PorA, P1.7, $2 \mu \mathrm{g} / \mathrm{mL}$; right, anti-PorA, P1.4, $10 \mu \mathrm{g} / \mathrm{mL}$. Row 2: JAR 3, $10 \mu \mathrm{g} / \mathrm{mL}$. Row 3: JAR 4, $50 \mu \mathrm{g} / \mathrm{mL}$. Row 4: JAR 3 plus JAR 4 (1 $\mu \mathrm{g} / \mathrm{mL}$ for each). The data are adapted from Ref. [44]. 